\title{
Keep in Mind: Pulmonary Embolism Due to the Use of Clomiphene Citrate
}

\author{
Akılda Tut: Klomifen Sitrat Kullanımına Bağıı Pulmoner Emboli
}

Buket Mermit Çilingir, Hanifi Yıldız, Aysel Sunnetcioglu

\section{Abstract}

A 28-year-old female patient was admitted with ongoing chest pain for one day, having started treatment for ovulatory dysfunction with clomiphene citrate 20 days prior. The patient's pulse rate was 120 bpm and blood pressure was 100/60 mmHg. Sinus tachycardia was detected on electrocardiography. Both hypoxia and hypocapnia were detected on an arterial blood gas test. The patient's d-dimer level was measured as $5.2 \mu \mathrm{g} / \mathrm{ml}$. A computed tomography angiography revealed filling defects in the right lower lobe pulmonary artery and lower lobe segment branches, consistent with pulmonary embolism. The ejection fraction was $65 \%$ on the transthoracic echocardiography and no thrombus was observed. The patient was diagnosed with pulmonary embolism due to clomiphene citrate use, and started on anticoagulation therapy with bemiparin sodium, and was subsequently discharged. Acute pulmonary embolism due to the use of clomiphene citrate is an uncommon but life-threatening complication when encountered. Physicians should be aware of the potential risk of pulmonary embolism.

Key words: Pulmonary embolism, clomiphene citrate, infertility.

\begin{abstract}
Özet
Yirmi sekiz yaşındaki bayan hasta bir gündür devam eden göğüs ağrısı nedeniyle başvurdu. Ovulatuar disfonksiyonun klomifen sitrat ile tedavisi 20 gün önce başlatılmıştı. Hastanın nabız hızı 120 vuru / dakika ve kan basınc 100/60 mmHg idi. Elektrokardiyografide sinüs taşikardisi saptandı. Arteriyel kan gazı testi sonucunda hem hipoksi hem de hipokapni tespit edildi. D-dimer seviyesi $5.2 \mu \mathrm{g} / \mathrm{ml}$ olarak ölçüldü. Bilgisayarlı tomografi anjiyografisinde sağ alt lob pulmoner arter ve alt lob segment dallarında pulmoner emboli ile uyumlu dolum defektleri görüldü. Transtorasik ekokardiyografide ejeksiyon fraksiyonu \%65 idi ve trombüs izlenmedi. Hastaya klomifen sitrat kullanımına bağlı pulmoner emboli tanısı kondu. Bemiparin sodyum ile antikoagülan tedavi başlandı ve hasta taburcu edildi. Klomifen sitrat kullanımına bağlı akut pulmoner emboli, nadir görülen ancak karşılaşıldığında yaşamı tehdit eden bir komplikasyon olabilir. Doktorlar olası pulmoner emboli riskinin farkında olmalıdır.
\end{abstract}

Anahtar Sözcükler: Pulmoner emboli, klomifen sitrat, infertilite.
Department of Chest Diseases, Van Yüzüncü Yıl University Faculty of Medicine, Van, Turkey
Van Yüzüncü Yıl Üniversitesi Tıp Fakültesi, Göğüs Hastalıkları Anabilim Dalı, Van

Submitted (Başvuru tarihi): 15.01.2021 Accepted (Kabul tarihi): 21.03.2021

Correspondence (iletişim): Buket Mermit Çilingir, Department of Chest Diseases, Van Yüzüncü Yıl University Faculty of Medicine, Van, Turkey

e-mail: buketmermitcilingir@gmail.com 
Pulmonary embolism (PE) is a common disease with high morbidity and mortality. Inactivity, trauma, surgery, congestive heart failure, autoimmune diseases, oral contraceptive use and hereditary thrombophilia are the most common causes (1). Clomiphene citrate, prescribed for ovulation induction treatment, is actually thought to be safe and has a low side effect profile.

It should be kept in mind that acute pulmonary embolism is a rare but potentially fatal complication that is associated with the use of clomiphene citrate (2). In this case report, a patient with pulmonary embolism due to clomiphene citrate use is described.

\section{CASE}

A 28-year-old female patient with no previous health problems was taken to the emergency department of Yüzüncü Yıl University Faculty of Medicine with back and chest pain that had started 1 day prior. There was no indication of systemic disease, trauma, surgery or allergy in the patient's medical history. She had a ten-year smoking history; there were no chronic diseases in the family history. Clomiphene citrate (50 mg/day) treatment was started 20 days prior due to ovulatory dysfunction.

A physical examination revealed a moderate general condition. The patient's pulse rate was $120 \mathrm{bpm}$ and blood pressure was $100 / 60 \mathrm{mmHg}$. Sinus tachycardia was detected on electrocardiography. Laboratory tests were requested, and a complete blood count, levels of electrolytes and cardiac parameters, and liver and kidney function test results were normal. Both hypoxia and hypocapnia were detected as a result of arterial blood gas test. D-dimer level was measured as $5.2 \mu \mathrm{g} / \mathrm{ml}$ (reference range $0-0.5 \mu \mathrm{g} / \mathrm{ml}$ ). As a result of our findings, a pulmonary embolism was considered in the patient. Computed tomography angiography revealed filling defects in the right lower lobe pulmonary artery and lower lobe segment branches, consistent with a pulmonary embolism (Figure 1 and 2).

An extensive workup was requested to investigate the etiology of the pulmonary embolism. Doppler ultrasonography revealed no thrombus in the deep veins of the lower or upper extremities. Transthoracic echocardiography was performed and no thrombus was observed, although a slight dilatation was observed in the right atrium, and the ejection fraction was measured as $65 \%$. There was no significant finding in the measurement of the levels of proteins $C$ and $S$, antithrombin, factor $V$ Leiden, antinuclear antibodies, homocysteine, cardiolipin antibodies, anti-double stranded DNA, antineutrophil cytoplasmic antibodies or lupus anticoagulant. Other causes of pulmonary embolism were excluded.

The patient was diagnosed with a pulmonary embolism due to clomiphene citrate use. Anticoagulation treatment was started with Bemiparin sodium, and the patient was discharged due to having no other risk factors for pulmonary embolism, with the planned use of bemiparin sodium for three months.

\section{DISCUSSION}

Clomiphene citrate is a non-steroidal agent that can induce ovulation in anovulatory women (3), and is generally the drug of choice for the treatment of ovulatory dysfunction, being inexpensive, easily applicable and with minimal side effects (4).

In cyclic clomiphene citrate therapy, ovulatory response is mediated by gonadotropins released from the pituitary. This stimulates the maturation of the ovarian follicle and the development of the corpus luteum. The pituitary plays a role in increasing both plasma estradiol level and plasma gonadotropin level, as well as ovarian response (5).

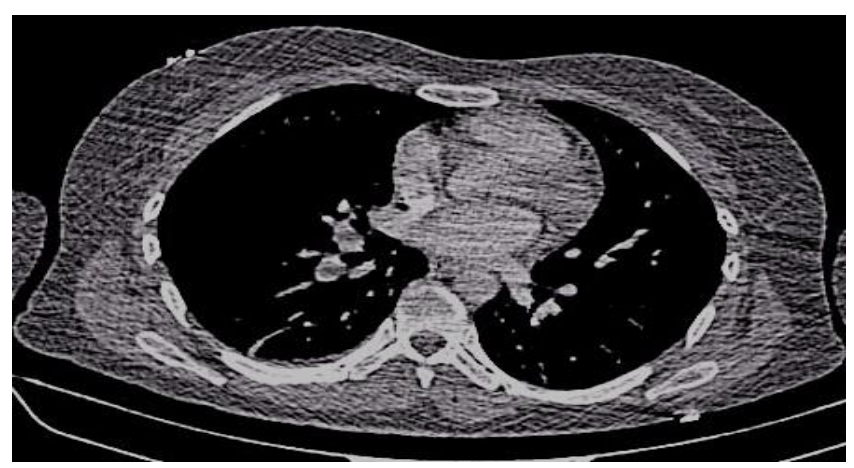

Figure 1: Thorax Computed Tomography Angiography showed filling defects at right lower lobe pulmonary artery and bilateral segmental bronchi

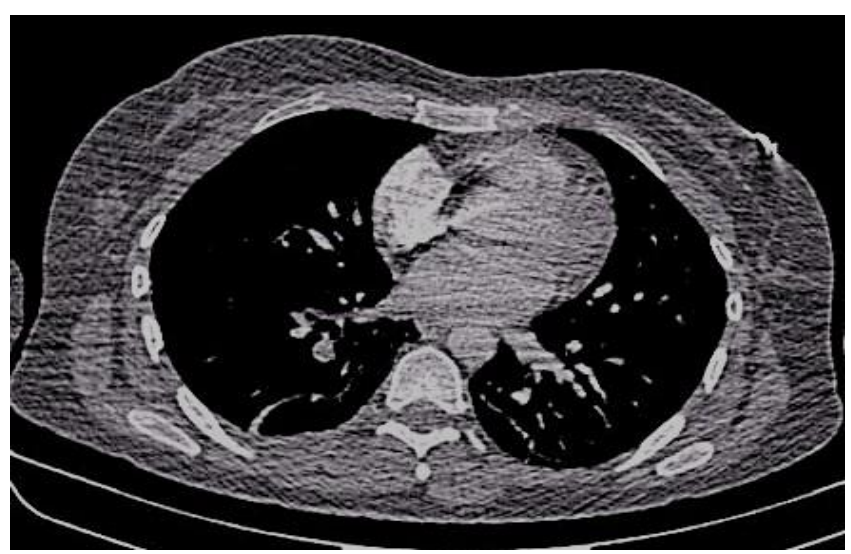

Figure 2: Thorax Computed Tomography Angiography showed filling defects at right lower lobe pulmonary artery and bilateral segmental bronchi 
Clomiphene citrate is administered orally on the third to fifth day after the onset of menstruation (6), and is absorbed in the gastrointestinal tract. The drug and its metabolites are not changed by the liver and are excreted in the feces. Its biological half-life is 5-6 days (7).

Abdominal and pelvic complaints such as hot flushes, distension, swelling or pain, ovarian enlargement and eye blur are common side effects. The symptoms, similar to the hot flushes seen in menopause, usually disappear after treatment is discontinued, while abdominal symptoms are mostly related to ovulation, premenstrual syndrome or ovarian enlargement. Rarer cardiovascular and pulmonary side effects include arrhythmia, chest pain, tachycardia, pulmonary edema, hypertension, palpitations, pulmonary embolism, shortness of breath and thrombophlebitis (5).

Like many other hormonal agents, clomiphene citrate can cause hypercoagulation and can slow the flow of blood, which has been attributed to the overproduction of vasoactive substances and ovarian hormones. There have been many studies reporting thromboembolic complications of clomiphene citrate, including myocardial infarction (8) pulmonary thromboembolism $(9,10)$ and ischemic stroke (11).

Aside from clomiphene citrate, other agents aimed at providing ovarian stimulation have also been reported to be associated with pulmonary embolism (12). Hormone replacement therapy increases the risk of PE by 2-5 times (13). In the present case, clomiphene citrate use may have predisposed our patient to pulmonary embolism, or even to have precipitated pulmonary embolism.

Recurrent arterial and venous thrombosis may occur in antiphospholipid syndrome, which is a hypercoagulable disease that is usually detected in the third or fourth decade of life, and may be accompanied by an autoimmune disease such as systemic lupus erythematosus. Nephrotic syndrome and factor $V$ Leiden mutations are associated with procoagulation and pulmonary embolism in young people (13), although serum blood samples for connective tissue disease, systemic vasculitis and hypercoagulation states were negative, leading to such diagnoses being excluded in the present case. We considered that the cause of pulmonary embolism to be clomiphene citrate in our case.

\section{CONCLUSION}

The use of clomiphene citrate for ovulation induction is considered a safe option, although it should be kept in mind that acute pulmonary embolism is a rare but poten- tially fatal complication associated with its use. Physicians should be aware of the potential risk, especially in patients with associated risk factors for pulmonary embolism. Further investigations are warranted to clarify the relationship between clomiphene citrate and pulmonary embolism.

\section{CONFLICTS OF INTEREST}

None declared.

\section{AUTHOR CONTRIBUTIONS}

Concept - B.M.Ç., H.Y., A.S.; Planning and Design B.M.Ç., H.Y., A.S.; Supervision - B.M.Ç., H.Y., A.S.; Funding - B.M.Ç., H.Y.; Materials - B.M.Ç., A.S.; Data Collection and/or Processing - B.M.Ç., A.S.; Analysis and/or Interpretation - B.M.Ç., H.Y.; Literature Review B.M.Ç.; Writing - B.M.Ç.; Critical Review - B.M.Ç., H.Y., A.S.

\section{YAZAR KATKILARI}

Fikir - B.M.Ç., H.Y., A.S.; Tasarım ve Dizayn - B.M.Ç., H.Y., A.S.; Denetleme - B.M.Ç., H.Y., A.S.; Kaynaklar B.M.Ç., H.Y.; Malzemeler - B.M.Ç., A.S.; Veri Toplama ve/veya İşleme - B.M.Ç., A.S.; Analiz ve/veya Yorum B.M.Ç., H.Y.; Literatür Taraması - B.M.Ç.; Yazıyı Yazan B.M.Ç.; Eleştirel İnceleme - B.M.Ç., H.Y., A.S.

\section{REFERENCES}

1. Konstantinides SV, Meyer G, Becattini C, Bueno H, Geersing GJ, Hariola VP, et al. 2019 ESC Guidelines for the diagnosis and managementof acute pulmonary embolism developed in collaboration with the European Respiratory Society (ERS). Eur Heart J 2019; 21:543-603. [CrossRef]

2. Practice Committee of the American Society for Reproductive Medicine. Use of clomiphene citrate in women. Fertil Steril 2006; 86:187-93. [CrossRef]

3. Juan A Garcia-Velasco, Manish Banker; Infertility Management Series, Polycystic Ovarian Syndrome Diagnosis and Management, First Edition: 2017.

4. National Colloborating Centre for Women's and Children's Health or National Institute for Health and Care Excellance. Fertility: assesment and treatment for people with fertility problems. London: RCOG Press; 2013.

5. Ekpo G, Moy I, Pavone ME, Milad MP. The use of clomiphene citrate for ovulation induction: When, why, and how? Contemporary Ob/Gyn 2011 : 56;42-52.

6. Yilmaz S, Unal F, Yilmaz E, Yuzbasıoglu D, Erkal-Ilhan S. Evaluation of the genotoxicity of clomiphene citrate. Mu- 
tat Res Genet Toxicol Environ Mutagen 2014; 759:21-7. [CrossRef]

7. Asmatullah SN, Ara C. Teratogenic and embryotoxic effects of clomiphene citrate in developing mice. Asian Australas J Anim Sci 2011 ; 24:1053-9. [CrossRef]

8. Study of possible correlation between myocardial infarction and clomiphene citrate. Acailable at: http://factmed.com/ study-clomiphene\%20citratecausing myocardial\%20infarction. php. Accessed Apr 24, 2018.

9. Chamberlain RA, Cumming DC. Pulmonary embolism during clomiphene therapy for infertility in a male: a case report. Int J Fertil 1986; $31: 198-9$.

10. Benshushan A, Shushan A, Paltiel O, Mordel N, Laufer N. Ovulation induction with clomiphene citrate complicated by deep vein thrombosis. Eur J Obstet Gynecol Reprod Biol 1995; 62:261-2. [CrossRef]

11. Inbar OJ, Levran D, Mashiach S, Dor J. Ischemic stroke due to induction of ovulation with clomiphene citrate and menotropins without evidence of ovarian hyperstimulation syndrome. Fertil Steril 1994; 62:1075-6. [CrossRef]

12. Girolami A, Scandellari R, Tezza F, Paternoster D, Girolami B. Arterial thrombosis in young women after ovarian stimulation: case report and review of the literature. J Thromb Thrombolysis 2007; 24:169-74. [CrossRef]

13. Arseven O, Ekim N, Müsellim B ve ark. Türk Toraks Derneği, Pulmoner Tromboembolizm Tanı ve Tedavi Uzlaşı Raporu - 2015. http://www.toraks.org.tr. 